\title{
Transfer of cow's milk $\beta$-lactoglobulin to human serum after a milk load: a pilot study
}

\author{
J A Lovegrove, D L Osman, J B Morgan, S M Hampton
}

\begin{abstract}
A sensitive and specific enzyme linked immunosorbent assay (ELISA) was developed for the quantification of cow's milk $\beta$ lactoglobulin in human serum. The assay had a sensitivity of $80 \mathrm{pg} / \mathrm{ml}$ ( 2 standard deviations from zero) and did not cross react significantly with any other tested milk proteins. The absorption of cow's milk $\beta$-lactoglobulin and $\beta$ lactoglobulin immunoglobulin $G$ antibody levels after a milk load was investigated in eight healthy non-allergic individuals. There was a significant variation in the circulating $\beta$ lactoglobulin antigen levels during the six hour period after feeding $(p<0.01)$ for the combined data. A biphasic absorption pattern was seen in all subjects except one subject who had undetectable levels. No significant variation with time was observed for the $\beta$-lactoglobulin IgG antibody levels and no correlation was found between the $\beta$-lactoglobulin antigen levels and the $\beta$-lactoglobulin IgG antibody levels. This pilot study offered information on the quantity of immunogenic cows' milk protein transferred to the blood after a milk load in non-allergic healthy adults and confirmed a biphasic profile of antigen transfer. The sensitivity of the assay used has shown that transfer of food antigen does occur in the majority of healthy nonallergic subjects.

(Gut 1993; 34: 203-207)
\end{abstract}

A large number of mechanisms are present within the gastrointestinal tract which provide for the exclusion of undigested macromolecules from systemic compartments. Despite the occurrence of these components there is increasing experimental and clinical evidence that large antigenically active molecules can penetrate the intestinal epithelial surface, not in sufficient quantities to be of nutritional importance, but in quantities that can be of immunological significance..$^{1-3}$ Paganelli and Levinsky ${ }^{2}$ detected $\beta$-lactoglobulin in the blood of three healthy individuals after a $1 \cdot 2$ litre milk load. Uptake of dietary antigens in healthy adults was also observed by Kilshaw and Cant, ${ }^{4}$ who measured nanogram quantities of ovalbumin in the serum of lactating women after ingestion of one raw egg and Husby et $a l^{5}$ who observed ovalbumin in the sera from seven of eight healthy adults, after the intake of $60 \mathrm{ml}$ raw egg and $500 \mathrm{ml}$ milk.

The clinical interest in absorped food antigens and the subsequent antibody development, is of increasing concern because of its association with a large number of pathological conditions. The gastrointestinal tract diseases possibly associated with antigen absorption are gastrointestinal tract allergy, inflammatory bowel disease, gluten induced enteropathy, toxigenic diarrhoea, chronic hepatitis, necrotising enterocolitis and autoimmune disease. ${ }^{6}$

In order to quantify how much mucosal permeation may be considered abnormal, it is essential to determine the quantity absorbed by healthy individuals. Antibodies to dietary antigens have been detected in the sera of a considerable proportion of the normal population. ${ }^{7-10}$ The antibody titres were reported to decline during the first decade of life in normal children, but not in food allergic children." The presence of the antibodies, and the immune response after food antigen ingestion, is an area of increasing interest.

The aim of the study was to investigate the absorption of a cow's milk protein, $\beta$ lactoglobulin, after a milk load, in addition to the quantification of the circulating $\beta$-lactoglobulin IgG antibody levels using a previously developed indirect ELISA. ${ }^{9}$ An acute feeding study was performed on healthy, non food allergic subjects, over a six hour period.

\section{Methods}

APPARATUS

A microtitre plate washer and plate reader were purchased from Flow Laboratories (Billinghurst, Sussex).

\section{MATERIALS}

Polystrene Immuno-2 microtitre plates were obtained from Dynatech Laboratories (Billinghurst, Sussex). 3,3',5,5' tetra methyl benzidene was purchased from Boehringer Mannheim (Mannheim, Germany). Horseradish peroxidase was obtained from Bioenzyme (Gwent, Wales). $\beta$-lactoglobulin, other milk proteins and Sephadex G75 were purchased from Sigma (Poole, Dorset). All other chemicals were obtained from BDH Chemicals (Poole, Dorset).

\section{ANTISERUM PRODUCTION}

A three month old female half lop rabbits (high antibody producing strain, Ranch Rabbits Ltd) was primed with $1 \mathrm{mg}$ of $\beta$-lactoglobulin. Nonulcerative complete adjuvant (gift from B A Morris) was emulsified with the $\beta$-lactoglobulin in a 1:1 ratio and injected intramuscularly in four sites into the upper legs. The rabbit was bled weekly and the antibody titre assessed. The animal was boosted with half the priming dose after three months. The antiserum used in the 
assay was obtained nine days after boosting (Batch no MF/R/HLlA).

PURIFICATION OF ANTISERUM

The antiserum was purified using a $\beta$ lactoglobulin antigen affinity column. $1000 \AA$ aminopropyl porous silica beads $(0.25 \mathrm{~g})$ were placed into a disposable column with $2 \mathrm{ml} 0.05 \mathrm{M}$ phosphate buffered saline $\mathrm{pH} \mathrm{7.4}$. To this, $0.5 \mathrm{ml}$ of gluteraldehyde (Grade II $25 \%$ aqueous) was added and rolled for 2 hours. The beds were then washed thoroughly with $0.05 \mathrm{M}$ phosphate buffered saline $\mathrm{pH} 7 \cdot 4$. $\beta$-lactoglobulin $(5 \mathrm{mg})$ was dissolved in sodium acetate buffer $\mathrm{pH} 4 \cdot 4$ $(5 \mathrm{ml}) .0 \cdot 05 \mathrm{M}$ phosphate buffered saline $\mathrm{pH} 7 \cdot 4$ was expelled from the column before the addition of this solution, and the column was then rolled for four hours. The liquid was run through and discarded. The column was washed thoroughly with $0.05 \mathrm{M}$ phosphate buffered saline $\mathrm{pH} 7 \cdot 4$. Three millilitres of $0.05 \mathrm{M}$ phosphate buffered saline pH $7 \cdot 4$ and 0.22 g glycine was added and rolled for one hour. This was left to stand overnight before washing again with $0.05 \mathrm{M}$ phosphate buffered saline $\mathrm{pH} 7 \cdot 4$. Three millilitres of $0.3 \% \mathrm{HCl}$ in $0.05 \mathrm{M}$ phosphate buffered saline $\mathrm{pH} 7 \cdot 4$ was then added and rolled for 30 minutes. The column was finally washed thoroughly with $0.05 \mathrm{M}$ phosphate buffered saline $\mathrm{pH} 7 \cdot 4$ and was ready for use.

For affinity purification the following procedure was followed: $2 \mathrm{ml}$ of antiserum was passed down the antigen affinity column and rolled for 30 minutes. The antiserum was then run through and collected. After washing with $0.05 \mathrm{M}$ phosphate buffered saline $\mathrm{pH} 7 \cdot 4,3 \mathrm{ml}$ $0 \cdot 1 \mathrm{M} \mathrm{HCl}$ glycine $\mathrm{pH} 2 \cdot 2$ was applied, and then rolled for 30 minutes. An additional $2 \mathrm{ml}$ of $\mathrm{HCl}$ glycine $\mathrm{pH} 2.2$ was added and the eluate collected. The column was then reequilibrated by the addition of $0.05 \mathrm{M}$ phosphate buffered saline $\mathrm{pH} 7 \cdot 4$, and stored in $0.05 \mathrm{M}$ phosphate buffered saline $\mathrm{pH} 7 \cdot 4$ with $0.02 \%$ thiomersal as a preservative. The eluate was dialysed overnight against $0 \cdot 05 \mathrm{M}$ phosphate buffered saline $\mathrm{pH} 7 \cdot 4$ to return it to a neutral $\mathrm{pH}$. The protein content was determined by recording the optical density at $280 \mathrm{~nm}$.

\section{ASSAY PROTOCOL}

The inner 60 wells of an Immuno- 2 polystyrene microtitre plate were coated with $200 \mu$ l of affinity purified rabbit $\beta$-lactoglobulin antibodies $(5 \mu \mathrm{g} / \mathrm{ml})$ in $0 \cdot 1 \mathrm{M}$ bicarbonate/carbonate buffer $\mathrm{pH} 9 \cdot 4$, and incubated in a moist chamber at $37^{\circ} \mathrm{C}$ for three hours. The plate was then washed three times in $0.05 \mathrm{M}$ phosphate buffered saline with $0.1 \%$ gelatin and $0.05 \%$ Tween $20 \mathrm{pH} 7 \cdot 4$ (PBSGT) $(250 \mu \mathrm{l} /$ well). All further dilutions and washing steps were carried out in this buffer. $\beta$-lactoglobulin standard was added to the plate, in duplicate, in the range 0.04-10 $\mathrm{ng} / \mathrm{ml}$ diluted in immunostripped pooled fasted human serum at a dilution of $1: 4$ in assay buffer $(200 \mu \mathrm{l} /$ well $)$. The samples and quality controls were also added to the appropriate wells diluted 1:4 in assay buffer $(200 \mu \mathrm{l} /$ well). The plate was then incubated at $4^{\circ} \mathrm{C}$ overnight. After washing, $200 \mu \mathrm{l} /$ well of the rabbit anti- $\beta$-lactoglobulin enzyme label (initial dilution 1:500) was added to all. wells and incubated at $37^{\circ} \mathrm{C}$ for two hours. The rabbit anti$\beta$-lactoglobulin enzyme label was produced according to the method of Beyzavi et al.$^{12}$ After washing again, 3,3',5,5' tetra methyl benzidene substrate was added to all wells and incubated at $37^{\circ} \mathrm{C}$ for 15 minutes $(150 \mu \mathrm{l} /$ well $)$. The reaction was stopped by the addition of $2.5 \mathrm{M}$ sulphuric acid $(50 \mu \mathrm{l} /$ well $)$. The coloured end point was read at $450 \mathrm{~nm}$. A standard curve was constructed and the levels of $\beta$-lactoglobulin in the samples calculated.

\section{VALIDATION OF ASSAY}

Recovery of exogenous $\beta$-lactoglobulin was performed by adding a range of concnetrations $(0.5-$ $8 \mathrm{ng}$ ) of $\beta$-lactoglobulin standard to a pooled serum sample. The recovery was subsequently calculated. Parallelism of endogenous $\beta$-lactoglobulin antigen and exogenous $\beta$-lactoglobulin standard was performed in addition to crossreactivity of the ELISA with $\alpha$-lactalbumin, bovine serum albumin, $\alpha$-casein (cow), $\alpha$-casein (goat), $\alpha$-casein (sheep) and Peptijunior (Cow and Gate, Trowbridge, Wilts). Reproducibility of the assay was quantified by performing intraassay coefficient of variation of the high, medium and low quality control (eight) and interassay coefficient of variation (10).

\section{SUBJECTS}

Eight young healthy adult subjects, five male and three female, were recruited from the undergraduate student population at the University of Surrey. The study received ethical committee approval and all of the subjects were given full details of the study before agreeing to participate and gave written consent. The requirement for inclusion in the study was that no history of food intolerance was reported by the subjects.

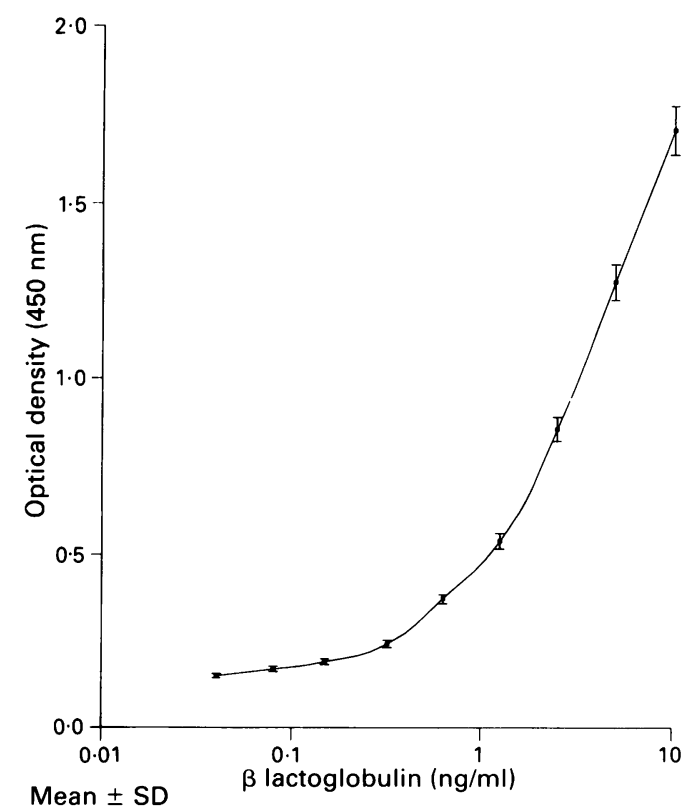

Figure 1: Standard curve of $\beta$-lactoglobulin ELISA in human serum. (Values mean $(S D)$.) 
TABLE I Intra and inter coefficient of variation of $\beta$-lactoglobulin antigen ELISA

\begin{tabular}{ll}
\hline & Sera \\
\hline Intra CV & \\
High & $4 \cdot 45(0 \cdot 25) \mathrm{ng} / \mathrm{ml}$ \\
$\mathrm{CV}$ & $6 \%$ \\
Med & $1 \cdot 82(0 \cdot 07) \mathrm{ng} / \mathrm{ml}$ \\
$\mathrm{CV}$ & $4 \%$ \\
Low & $0 \cdot 24(0.001) \mathrm{ng} / \mathrm{ml}$ \\
CV & $4 \%$ \\
Inter CV & $15 \%$ \\
\hline
\end{tabular}

Individuals were included if they suffered from allergies other than food allergies. The subjects were weighed, using a metric beam balance (accurate to $100 \mathrm{~g}$ ) and height measured using a stadiometer (accurate to $1 \mathrm{~cm}$ ). All subjects were asked to complete a questionnaire regarding age, sex, drinking and smoking habits, and the presence of any family allergies.

\section{STUDY PROTOCOL}

The subjects were all fasted overnight and were only allowed to consume water for the duration of the study period. Each subject was given $10 \mathrm{ml} / \mathrm{kg}$ body weight of pasteurised full fat milk (Ryde Farm Estate Dairy, Leatherhead, Surrey) to consume orally over a period of 10 minutes. Blood samples $(15 \mathrm{ml})$ were collected via a venous cannula at $-10,0,15,30,45,60,90,120$, $135,150,165,180,195,210,240,300$, and 360 mins. The blood was collected into a plain sterile glass tube and allowed to clot for one hour. It was then spun at $1000 \mathrm{~g}$ for five minutes in a centrifuge. The serum was removed from the clot, aliquoted and stored at $-20^{\circ} \mathrm{C}$ until required for analysis.

\section{BIOCHEMICAL ANALYSIS}

For each sample collected $\beta$-lactoglobulin antigens were measured using the described $\beta$ lactoglobulin ELISA. In addition $\beta$-lactoglobulin IgG antibodies were also measured using an ELISA previously reported by Hampton et al. ${ }^{9}$

\section{STATISTICAL ANALYSIS}

An one way analysis of variance and Pearson's correlation were used as the statistical test where appropriate.

\section{Results}

\section{ELISA DEVELOPMENT}

A standard curve for the $\beta$-lactoglobulin antigen ELISA is shown in Figure 1. The sensitivity of the $\beta$-lactoglobulin antigen ELISA was $80 \mathrm{pg} / \mathrm{ml}$ (2 SD from zero). The inter and intra-assay

TABLE II Cross reactivity of $\beta$-lactoglobulin antigen ELISA

\begin{tabular}{lllllll}
\hline & $\alpha$-la & $P f$ & $B S A$ & $\begin{array}{l}\alpha \text {-cas } \\
(\text { cow })\end{array}$ & $\begin{array}{l}\alpha \text {-cas } \\
(\text { goat })\end{array}$ & $\begin{array}{l}\alpha \text {-cas } \\
(\text { sheep })\end{array}$ \\
\hline Sera & $<0.001$ & $<0.01$ & $<0.001$ & $<0.001$ & $<0.001$ & $<0.001$ \\
\hline
\end{tabular}

NB $\alpha$-la $=\alpha$-lactalbumin, Pf $=$ Peptijunior, BSA = bovine serum albumin, $\alpha$-cas $=\alpha x-$ casein .

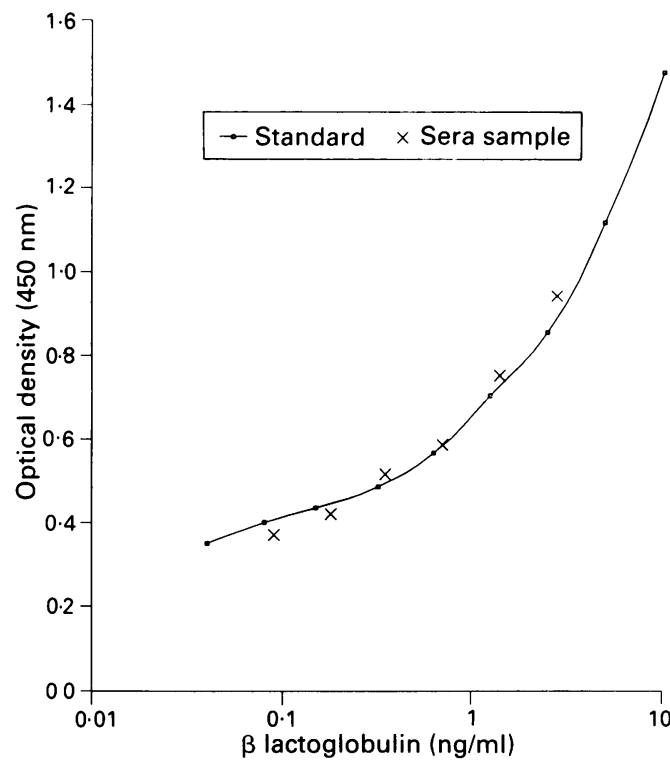

Figure 2: Standard curve demonstrating parrallelism between added $\beta$-lactoglobulin and $\beta$-lactoglobulin in human serum.

coefficient of variation for the $\beta$-lactoglobulin antigen ELISA is shown in Table I. Assay parallelism is shown in Figure 2 and the cross reactivity of the assay is shown in Table II. The mean recovery of exogenous $\beta$-lactoglobulin added to serum in the range of $0 \cdot 5-8 \cdot 0 \mathrm{ng}$, was 98\% (range $85-105 \%$ ).

\section{MILK LOAD STUDY}

All subjects were within the recommended body mass index range, with the men and women having comparable values. The age of the subjects was 21 (1) years [19-22] (mean (SD) [range]) and the body mass index was 21.4 (2.6) [17.8-24.6] (mean (SD) [range]).

One subject smoked regularly. One male and one female subject exceeded the recommended alcohol intake of 14 units/week for women and 21 units/week for men. Two subjects reported having a mild pollen allergy, in addition to their parents. One subject's mother was also reported to suffer from a mild pollen allergy. No other allergies were reported.

One subject had circulating $\beta$-lactoglobulin levels which were significantly higher than the remaining subjects $(\mathrm{p}<0.01)$. Another subject had undetectable $\beta$-lactoglobulin levels. $\beta$ lactoglobulin antigen was detected in the circulation of the majority of subjects 30 minutes after administration, and peak levels were observed between 30-90 minutes and 165-240 minutes. The antigen absorption was in a biphasic pattern as shown in Figure 3. No significant correlation was revealed between the levels of $\beta$-lactoglobulin antigen and $\beta$-lactoglobulin IgG antibody in sera samples for any time point. The $\beta$-lactoglobulin IgG antibody levels of the subjects is shown in Figure 4. No significant change in the $\beta$-lactoglobulin IgG antibody levels with time was detected. The mean $\beta$-lactoglobulin antigen levels over a 6-hour period after a milk load are shown in Figure 3. A significant variation of these mean antigen levels over time was observed $(\mathrm{p}<0.001)$. 


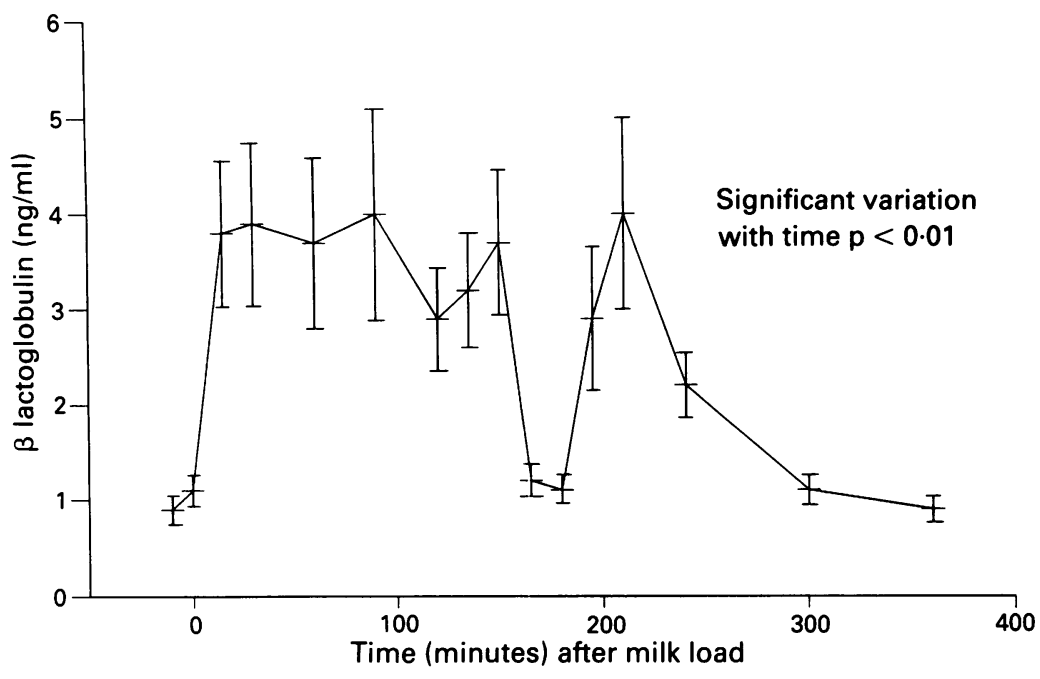

Figure 3: Serum $\beta$-lactoglobulin levels in adults (eight) over a six hour period after a test meal containing $10 \mathrm{ml}$ milk/kg body weight (Mean (SE).)

\section{Discussion}

A sensitive, specific and reproducible ELISA was developed for the determination of cow's milk $\beta$-lactoglobulin in human sera samples. The assay sensitivity was of utmost importance, as the levels of circulating $\beta$-lactoglobulin in sera had been reported to be between $0.01-0.03 \mathrm{ng} /$ $\mathrm{ml}^{13}$ and $0 \cdot 1-3 \mathrm{ng} / \mathrm{ml}^{2}{ }^{2}$ Discrepancy in the reported levels of the protein in human serum probably reflected the methods used, subjects studied and antiserum avidity. The disadvantage inherent in all the immunoassay systems was the measurement of immunoreactivity, as opposed to the biological activity of the compound. The sensitivity of our assay $(80 \mathrm{pg} / \mathrm{ml})$ was comparable with, and in most cases higher than, other reported methods.

Validation of an assay was essential to determine how robust the assay was under routine use. Recovery of exogenous $\beta$-lactoglobulin from a test sample was satisfactory. The assay possessed negligible cross reactivity with all of the milk proteins tested.

In this study all but one subject had detectable

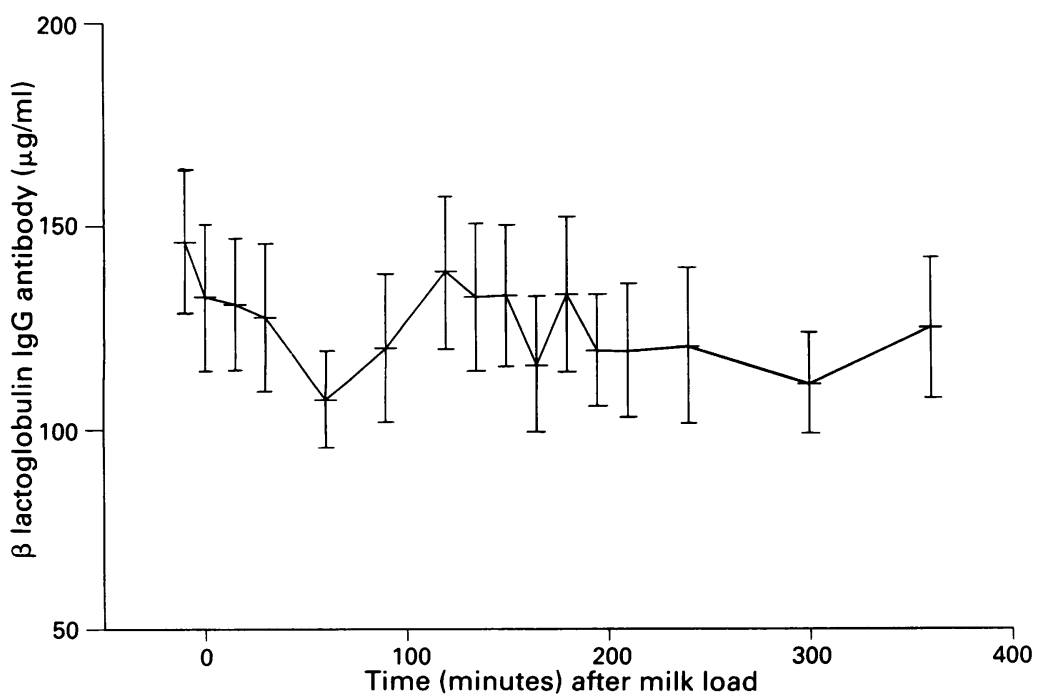

Figure 4: Serum $\beta$-lactoglobulin IgG antibody levels in adults (eight) over a six hour period after a test meal containing $10 \mathrm{ml}$ milk/kg body weight (Mean $(S E)$.) levels of $\beta$-lactoglobulin antigen in their sera, after a milk load which contained approximately $1.9-2.5 \mathrm{~g} \beta$-lactoglobulin protein. One of the subjects had circulating $\beta$-lactoglobulin levels significantly higher than the remaining seven subjects after the milk load, although her basal $\beta$ lactoglobulin level was very low. The maximum antigen concentration in this subject was $25 \mathrm{ng} /$ $\mathrm{ml}$, which was considerably higher when compared to the $3 \mathrm{ng} / \mathrm{ml}$ maximum levels in normal individuals reported by Paganelli and Levinsky ${ }^{2}$ and the $2 \mathrm{ng} / \mathrm{ml}$ levels in infants with cows milk allergy, after a milk challenge. ${ }^{14}$ The maximum levels in the other subjects with detectable $\beta$ lactoglobulin, of between $1 \cdot 5-4.4 \mathrm{ng} / \mathrm{ml}$, however, were more in agreement with Paganelli and Levinsky $^{2}$ and Husby et al. ${ }^{14}$ In this study the antigen absorption was found to follow an approximate biphasic pattern, which was also reported by Paganelli and Levinsky. ${ }^{2}$ The mechanism for the reported biphasic pattern is unclear. More research into the possible reasons for the biphasic appearance of $\beta$-lactoglobulin antigens in the blood after a meal is essential. It could be postulated, however, that this reported absorption pattern may be in part caused by the presence and absorption of $\beta$-lactoglobulin antigens with different molecular weights, which are at varying stages of digestion. It would therefore seem appropriate and interesting to examine the molecular weight of the $\beta$-lactoglobulin antigen detected, a procedure that will be investigated in future studies.

Trace amounts of $\beta$-lactoglobulin were found at the start of the study in a majority of the subjects. This has also been reported by Husby who found small quantities of ovalbumin 48 hours after egg ingestion, ${ }^{3}$ and $\beta$-lactoglobulin 24 hours after a milk challenge. ${ }^{14}$ This probably reflects the slow clearance of food antigens from the blood of some individuals, the significance of which is not clear, but does emphasise the need for an extended fasting period before the commencement of feeding studies.

The intestinal digestibility of food proteins influences the form in which they are absorped. $\beta$-lactoglobulin has been found to be the most resistant milk protein to enzyme hydrolysis ${ }^{1516}$ and is therefore absorped in greater quantities compared to other milk proteins in animal studies. ${ }^{16-18}$ Determination of the size distribution of the absorped food proteins is important, as it is believed to be involved in the induction of immunisation or tolerance, ${ }^{5}$ and would lead to a greater understanding of the resistance of the food protein to intestinal enzymic degradation. Animals studies, performed on mice, have confirmed that absorption of food antigens across the gut mucosa resulted in subtly altered tolerogenic forms. ${ }^{1920}$ The occurrence of altered forms after mucosal transfer in man is unknown, but may help to explain the high tolerance expressed by the majority of individuals to a vast array of transferred foreign proteins. The size of the $\beta$-lactoglobulin absorped in a study on children who were intolerant to cows' milk protein corresponded to small immune aggregates. ${ }^{1+}$ Another important consideration is the presence and influence of $\beta$-lactoglobulin specific antibodies within serum samples on the 
quantification of $\beta$-lactoglobulin antigen by ELISA. The antibodies themselves do not seem to interfere with the ELISA directly, as recovery of exogenous $\beta$-lactoglobulin within a pooled serum sample containing detectable $\beta$-lactoglobulin IgG antibodies was good. The influence of the binding of $\beta$-lactoglobulin specific antibody to absorped $\beta$-lactoglobulin with the formation of immune complexes, however, may be significant in underestimation of the circulating $\beta$-lactoglobulin within the serum samples. It is not certain whether the reported assay is measuring free $\beta$-lactoglobulin or that involved with immune complexes or both. Before this can be resolved further research is required to quantify the amount of $\beta$-lactoglobulin involved in immune complexes and determine their effect in the reported assay.

$\beta$-lactoglobulin IgG antibody levels were detected in all of the subjects, with the individual concentrations varying considerably. Despite the continuous antigenic challenge from daily milk ingestion, however, the antibody levels were relatively low. The $\beta$-lactoglobulin IgG antibody levels did not show any significant variation with time. This was also reported by Gallagher ${ }^{21}$ and Paganelli. ${ }^{22}$ An inverse relationship between the maximal serum levels of antigen after a meal, and the levels of serum $\beta$ lactoglobulin IgG antibody, were only apparent in the subjects with high or low antibody levels. This was also reported by Husby $e t a l^{5}$ and Dannaeus et al. ${ }^{23}$ This could reflect the involvement of other antibody classes in the handling of the antigens.

This study has offered information about the transfer of cows' milk protein in non-allergic individuals after a milk load and has proved that detectable amounts of antigen are transferred in these individuals. Further work is required to determine the levels of $\beta$-lactoglobulin absorbed in groups of susceptable subjects. Comparison of milk antigen levels in atopic individuals and controls will determine whether more cows milk protein antigen is transferred in these individuals and has any significance in the manifestation of allergy or the immune response against them.

The authors would like to thank Cow \& Gate Ltd, Trowbridge, Wilts for their generous support of this work. We would also like to acknowledge the help of $\operatorname{Dr} M$. Crowder with the statistica analysis of the data. Lastly, we would like to thank the subjects without whom this trial would have been impossible.
1 Walker WA, Isselbacher KJ. Intestinal antibodies. $N$ Engl $\mathcal{F}$ Med 1977; 297: 767-73.

2 Paganelli R, Levinsky RJ. Solid phase radioimmunoassay for detection of circulating food protein antigens in human serum. F Immunol Meth 1980; 37: 333-41.

3 Husby S, Jensenius JC, Svehag S-E. Passage of undegraded dietary antigens into the blood of healthy adults. Further characterization of the kinetics of uptake and size districharacterization of the kinetics of uptake and size distri-

4 Kution of the antigen. Scand 7 Immunol 1986; 24: 447-55. ilshaw PJ, Cant AJ. The passage of maternal proteins into breast milk. Int Archs Allergy Appl Immunol 1984; 75: 8-15.

Husby S, Jensenius JC, Svehag SE. Passage of undigested dietary antigen into the blood of healthy adults. Quantification, estimation of size distribution, and relation of uptake to levels of specific antibodies. Scand F Immunol 1985a; 22: 83-92.

6 Walker WA. Role of the mucosal barrier in antigen handling by the gut. In: Brostoff J, Challacombe SJ, eds. Food allergy and intolerance. 1st ed. London: Baillère Tindall, 1987: 209-22.

7 Gunther M, Aschaffenburg RH, Parish WE, Coombes RRA. The levels of antibodies to cow's milk in the serum of normal human infants. Immunology 1960; 3: 296-305.

8 Husby S, Oxelius VA, Teiser B, Jensenius JC, Svehag SE. Humoral immunity to dietary antigens in healthy adults. Int Arch Allergy Appl Immunol 1985b; 77: 416-22.

9 Hampton SM, Morgan JB, Smith MR, Morris R, Lovegrove JA, Marks V. Circulating and secretory antibodies to specific

10 Lovegrove JA, Hampton SM, Morgan JB, Marks V. Quantification of total IgG levels against $\alpha$-casein in human serum samples serum. Biochem Soc Trans 1989; 17: 1059-60.

11 May CD, Remigio L, Feldman J, Bock SH, Carr RI. A study of serum antibodies to isolated milk proteins and ovalbumin in infants and children. Clin Allergy 1977; 7: 583-95.

12 Beyzavi K, Hampton SM, Kwasowski P, Fickling S, Marks V, Clift $R$. Comparison of HRP and alkaline phosphatase labelled antibodies in enzyme immunoassay. Ann Clin Biochem 1987; 24: 149-56.

13 Cavagni G, Paganelli R, Caffarelli C, D’Offizi GP, Bertolini P, Aiuti $F$, et al. Passage of food antigens into circulation of breast-fed infants with atopic dermatitis. Ann Allergy 1988; breast-fed $361-5$.

14 Husby S, Host A, Teisner B, Svehag S-E. Infants and children with cow milk allergy/intolerance. Allergy 1990; 45: 547-51.

15 Otani $\mathrm{H}$. Antigenicities of $\beta$-lactoglobulin treated with proteolytic enzymes. Fpn F Zootech Sci 1981; 52: 47-52.

16 Marcon-Genty D, Tome D, Dumontier A-M, Kheroua O, Desjeux JF. Permeability of milk protein across the intestinal epithelium in vitro. Reprod Nutr Dev 1989a; 29: 717-23.

17 Koritz TN, Suzuki S, Coombs RRA. Antigenic stimulation with proteins of cow's milk via oral route in guinea pigs and with proteins of cow's milk via oral route in guinea pigs and rats. 1. Measurement of antigenically intact $\beta$-lactoglobulin and casein in the gastrointestinal contents of duodenum, jejunum.

18 Marcon-Genty D, Tome D, Kheroua O, Dumontier A-M, Heyman M, Dasjeux J-F. TRansport of $\beta$-lactoglobulin across rabbit ileum in vitro. Am $\mathcal{F}$ P hysiol $1989 \mathrm{~b} ; 256$ : 943-8.

19 Bruce MG, Ferguson A. Oral tolerance to ovalbumin in mice: studies of chemically modified and 'biologically filtered' antigen. Immunology 1986; 57: 627-30.

20 Bruce MG, Ferguson A. The influence of intestinal processing on the immunogenicity and molecular size of absorbed, circulating ovalbumin in mice. Immunology 1986; 59: 285-300.

21 Gallagher PJ, Goulding NJ, Gibney MJ, Jones DB, Morgan $\mathrm{JB}$. Acute and chronic immunological response to dietary JB. Acute and chronic imm

22 Paganelli R, Atherton DJ, Levinsky J. Differences between normal and millk allergic subjects in their immune response after milk ingestion. Arch Dis Child 1983; 58: 201-6.

23 Dannaeus A, Inganäs $M$, Johansson SGO, Foucard $T$. Intestinal uptake of ovalbumin in malabsorption and food allergy in relation to serum IgG antibody and orally administered sodium cromoglycate. Clin Allergy 1979; 9: 263-70. 